A. Kustova, I. Rozmainsky

A. Kustova, e-mail: kustovaa@inbox.ru, KPMG Global,

I. Rozmainsky, e-mail: irozmainskij@hse.ru,

National Research University Higher School of Economics

\title{
EMPIRICAL ANALYSIS OF GENERALIZED TRUST IN MODERN RUSSIA
}

\section{Introduction}

Today the concept of trust plays an important role in economic theory, being, for example, a crucial part of the theory of transaction costs and one of the components of the individuals' social capital. Mill (1970) writes that trust promotes increasing of transactions by means of ensuring honest behavior. Arrow (1972) even suggests that most of the economic backwardness in the world is due to the lack of mutual trust. Furthermore, some empirical studies, such as the work of Zak and Knack (2001) or the newer work of Bjørnskov (2012), show that greater trust in society leads to the economic growth. However, the study of trust cannot be treated as complete, since there are very small amount of works devoted to the study of trust at the individual level, especially the lack of them is observed in Russia.

Trust is at the heart of trade and investment, and especially it is important in the financial market where people part with their money in exchange for promises. And the most significant event in the financial sector all over the world over the past few decades has undoubtedly been the 2008 crisis. The Russian economy has also suffered several significant recessions in recent years, the most serious of which were the crises of 2008 and 2014. It would be interesting to check whether there was a trust change after these events in Russia

The following work has two purposes:

1) identify the determinants of generalized trust (i.e. trust in people in general) in modern Russia, using panel approaches for discrete choice models (panel logit in our case);

2) check whether the economic crises of 20082009 and 2014-2015 affected the level of generalized trust with the assumption that the population older than working age was not affected, using the diff-in-diff strategy.

The remainder of the paper is organized as follows: Section 2 presents a literature review, consisting of 3 subsections on theoretical background, trust determinants analysis and crisis impact on trust level; Section 3 provides the description of data that will be used; Section 4 represents the results of the trust determinants analysis; Section 5 represents results of a diff-in-diff estimation and Section 6 concludes and describes once again key points of the following research.

\section{Literature review}

\subsection{What is trust?}

Different authors put different meaning in the concept of trust. For instance, Luhmann (2018) writes that trust is "a coping mechanism that allows individuals to manage the uncertainty and complexity of human social organization". We found definition of Sapienza and Zingales (2012) to be the most correct one. They suggest that trust "is the expectation that another person or institution will perform in a preferable way, or at least not detrimental to us, regardless of our ability to control".

It is customary to distinguish several classifications of trust: "how to trust" and "who to trust" Uslaner (2010). The first classification divides trust into strategic trust and moralistic trust (altruistic trust). The first one suggests that the trust is related to past experience with specific people. On the other hand, the central idea of moralistic trust is the belief that most people share your fundamental moral values, so you assume they are trustworthy.

Strategic trust can only lead to cooperation between people you know, so it can only solve problems of trust among a small number of people. We need moralistic trust to come to civic participation. The second classification divides trust into particularized trust and generalized trust. The first one relates to the trust in someone or something specific, for instance, in such institutions as family, or government. On the other hand, generalized trust applies to people in general. The last category of trust is analyzed in the following research.

\subsection{What determines trust?}

The study of determinants of trust is not a new direction of research, but we assume that there are still some findings to be made for at least two reasons. First of all, the largest part of papers are devoted to the study of trust determinants at the macro level, however, micro level analysis is not so popular among researchers up to now.

The second reason is that the vast majority of earlier works are based on data of Western countries: the United States and European countries - but such studies rarely concern countries aside from the Western ones and studies based on the post-Soviet countries (like Russia) are even less common. That is why the paper of Gleave, Robbins and Kolko (2012), where authors surveyed citizens of Uzbekistan, seems quite unique. 
Gleave, Robbins and Kolko (2012) point out that all the determinants of trust can be divided into four semantic groups: civil society, institutional quality, culture and values and demographic homogeneity. The determinants of the first group characterize individual's involvement in social activities, for instance, in volunteer work. It is assumed that people who take an active part in the life of society generally more trustful than others, since they have more opportunities to learn from past experiences and develop expectations about how others will treat them. The second group includes determinants that measure institutional quality. High quality of institutions guarantees the creation of incentives for trustworthy behavior, which in turn increases the trust of individuals in the society. (Dysfunctional government institutions can lead to the lack of the generalized trust, according to Rothstein and Stolle (2008)). The third group consists of the individuals' various cultural norms and values that can somehow affect their level of trust. And the last group of determinants reflects the degree of homogeneity in society while considering such social inequalities as income inequality, religious inequality and ethnic inequality. The latter pave the way for untrustworthy behavior and, hence, the level of citizens' trust decreases.

According to previous papers (Alesina and La Ferrara (2002), Hooghe et al. (2009), Uslaner (2002)), group of population that experience discrimination are prone to a lower level of trust. Historically discrimination on the basis of gender, according to the authors, is directed towards women. That is, theoretically women should trust less than men. This hypothesis is confirmed in a study of Algan and Cahuc (2010) on a sample of US citizens, descendants of immigrants from different countries. However, a completely opposite effect was found by Dohmen et al. (2008) on a sample of German citizens: in Germany, women tend to trust more than men. In Asian countries such as China, Japan, Singapore, South Korea, Taiwan and Vietnam (Tan and Tambyah (2011)), even though Confucian philosophy prefers male dominance, gender does not affect the level of trust. Also, men and women do not differ from each other regarding trust in Muslim countries Jamal (2007), probably because women there do not perceive their status as unfavorable.

Age is considered one of the strongest predictors of trust. It is believed that as people mature, they are more likely to trust others. There are two possible reasons for this: as people grow older, they either learn to recognize social signs and signals that indicate trustworthy behavior (Gambetta and Hamill (2005)), or they develop the propensity of generations to trust others (Putnam (2000)). This hypothesis is confirmed in a sample of German citizens Dohmen et al. (2008), for Asian countries (Tan and Tambyah (2011)), and on a sample of US citizens, descendants of immigrants from different countries (Algan and Cahuc (2010)). An unusual result was obtained on the sample of citizens of Uzbekistan Gleave, Robbins and Kolko (2012): the coefficient at a variable age was negative. The authors suggest that this effect can be typical for the former Soviet Union countries, where there is often a considerable divergence in views among older people (who lived long before the collapse of the USSR) and the younger generation.

It can not be said that marital status is a very strong factor influencing trust, however, in some studies it was found to be significant as well. Alesina and La Ferrara (2002) found that people who have experienced any kind of trauma, such as divorce, are less trusting.

In a study of Gleave, Robbins and Kolko (2012) on a sample of Uzbek citizens, the variable of number of children has a positive effect on the level of trust. But in the article of Welch et al. (2007) on a sample of US citizens, this variable is not significant.

People with a higher level of education tend to have a higher level of trust. Education, like age, gives the individual some experience and learn to recognize the features of credible information (Alesina and La Ferrara (2002), Freitag and Traunmüller (2009), Hooghe et al. (2009)). This is supported by study based on German and Swedish data (Stolle, 1998). The same result was received by Omelchenko, Maximova and Noyanzina (2018); these researchers analyzed data from six Russian border regions (Altai region, Jewish autonomous region, Transbaikal region, Krasnoyarsk region, Omsk region, Orenburg region). In the study based on data from Uzbekistan Gleave, Robbins and Kolko (2012) the coefficient of the variable education is significantly negative, that diverges from other studies (the finding which is similar to the case with variable of age). The authors say that this can also be explained by the peculiarity of the population of the post-Soviet countries.

Success in the labor market and greater income foster trust, as they provide people with the necessary resources to accept risk and therefore trust others (Brehm and Rahn (1997), Freitag and Traunmüller (2009)). This is confirmed by the large number of empirical works: the research of Paxton (2007), the research of Gleave, Robbins and Kolko (2012), Brehm and Rahn (1997), as well as Freitag and Traunmüller (2009) found that the status of the unemployed reduces the level of trust of the individual. At the same time, more high social status and more high incomes increase trust (Omelchenko, Maximova and Noyanzina (2018)). Income inequality decreases trust, as Bjørnskov (2007) proved using a sample of 74 countries. Moreover, Chan (2007) argued that if globalization leads to more unequal domestic income distribution in a country that it adversely affects generalized trust (although usually globalization increases trust).

Trust-formation processes can be also characterized by racial dimensions. Marschall and Stolle (2004) showed that generalized trust is not likely to develop among whites who live in low status neighborhood. But these researchers did not find this effect for blacks.

Researchers rarely use types of religions as determinants of trust in their models. Nevertheless, such works exist. For example, Delhey and Newton (2005) 
found that respondents who identify themselves with the Protestant faith demonstrated a higher level of trust (in a sample of 60 countries). The same result was received by Bjørnskov (2007) for a mentioned sample of 74 countries. But in the study of Algan and Cahuc (2010) on a sample of US citizens, descendants of immigrants from different countries, certain types of religion were insignificant.

\subsection{The crises and trust}

Trust is at the heart of trade and investment, and especially it is important in the financial market where people part with their money in exchange for promises Sapienza and Zingales (2012). And the most significant event in the financial sector all over the world over the past few decades has undoubtedly been the 2008 crisis. The Russian economy has also suffered several significant recessions in recent years, the most serious of which were the crises of 2008 and 2014. It would be interesting to check whether there was a generalized trust change after these events in Russia.

As far as we know, no such studies were made, however, there are some papers considering change of trust to different institutions, such as financial institutions and government institutions. Uslaner (2010) finds out that the economic crisis of 2008 led to a decrease in American citizens' confidence in financial and government institutions. As he writes, the public perception of the economic stimulus plan was noted by the beliefs that rich businessmen will receive special privileges, while ordinary people will not. Uslaner also mentions that, generally, decline in confidence is not due to short-term economic fluctuations, but to long-term trends, such as increase in income inequality. Nevertheless, the 2008 economic crisis is so deep that it can affect both the trust in institutions and the trust in people in general.

Gros and Roth (2009) investigates the change in the trust of European citizens after the 2008 crisis. He finds that confidence in European institutions, and in European Central Bank in particular, has declined since the beginning of the financial crisis. However, a diametrically opposite trend of change in the level of confidence in European and national institutions after the financial crisis was discovered. Trust in national governments (for Germany, France, Italy, Great Britain and Spain) has actually increased since the beginning of the financial crisis, which cannot be said about the United States, where, as shown in the previous article, was a significant decrease in citizens' trust.

Sapienza and Zingales (2012) also discover that confidence of American citizens after the crisis fell, but they find that it fell more for the stock market and less for banks and government. In addition, authors asked respondents what they thought was the main cause of the financial crisis: the greed of managers (appeared to be the most popular cause), excessive government intervention, lack of oversight, poor corporate governance, lack of regulation and global imbalances (appeared to be the least popular cause). And interesting is that people who attribute the crisis to global imbalances have shown a much higher level of confidence in the securities market. The same is true for those who blamed excessive government intervention. The lowest level of confidence is characteristic for those who see the cause of the crisis in the lack of oversight and lack of regulation. Also, a low level of trust in the stock market is typical for those who saw the cause of the crisis in the greed of managers or poor corporate governance. The last two categories of respondents also showed the greatest decline in the level of confidence in the last few months of 2008.

\section{Data}

\subsection{Data description}

The data we are going to work with are panel data on individuals and the source of this data is the RLMS-HSE survey. The undeniable advantage of this database for our study is, first of all, a large number of individual level observations and great diversity of variables corresponding to person's attitude to various aspects of life and variables representing various demographic measures.

The depended variable is the ordered variable of generalized trust, which takes the value of 0 , if the respondent states that "In dealing with other people, one must always be careful", 1 , if the respondent cannot say definitely whether he trusts or not (i.e. depending on the person he deals with and the situation) and 2 , if the respondent is sure that "Most people can be trusted". All the exogenous variables used in this paper will be discussed in the following section.

\subsection{Variable descriptions}

In the current study exogenous variables are divided into five semantic groups: nationality and religion, political confidence, job satisfaction, egalitarian values, place of residence and mobility. Some basic individual's characteristic which are likely to influence generalized trust are included as well. Detailed description and summary statistics of each variable can be found in Table A.8.

The set of basic determinants includes such individual's characteristics as gender, age, marital status, number of children, level of education, whether an individual lives in a countryside or not, whether an individual is unemployed or not and individual's income. Gender in the current study is represented by the dummy variable Male, which takes the value of 1 , if a respondent is male and 0 otherwise. The variable Age denotes the total number of years of the respondent. Marital status of is represented by four dummy variables: Single which takes the value of 1 , if an individual has never been married, Married - 1, if an individual is married or lives with a partner without a registered marriage, Divorced - 1, if an individual is divorced and does not have a partner and Widow - 1, if an individual is widow or widower. Later on in the regression models the variable Single is used as a reference group. The variable 
Children denotes the total number of respondent's children. Level of education is represented by four dummy variables: Education_1 which takes the value of 1, if an individual has incomplete secondary education, Education 2-1, if an individual has complete secondary education, Education_3 - 1, if an individual has complete specialized secondary education and $E d u$ cation 4-1, if an individual has higher education. Later on in the regression models the variable Education_1 is used as a reference group. Here we would like to note that in many studies the variable of education is used as the total number of years spent on education. But that is not completely correct, since, for example, the return of one year of primary school and one year of university is not the same. That is why we prefer to use categories to denote level of education.

According to Russian legislation, an individual is recognized as unemployed if he or she does not have a job, looks for it and is ready to start it, and finally he or she must be registered at the employment center in order to find a suitable job. Unfortunately, there is a very little number of such individuals in our sample, which can be harmful to the following regression analysis. So, instead, we mark a person as unemployed if he or she does not have a job, looks for it and is ready to start it, but does not registered at the employment center.

The variable of income in the current study is presented in the two ways. At first we use the variable of the actual income of an individual (Income), namely the total monthly income, including all possible cash inflows: wages, pensions, transfers from relatives, etc. In this study actual income values were deflated, i.e. all transformed to levels which are comparable (2012 and 2016 to 2006). The vast majority of researchers use the actual income as an exogenous variable when analyzing generalized trust. Secondly, it seemed to us reasonable to add to the model instead of the variable of actual income the income expressed in the form of some selfassessment of people of their income. This variable is a scale from 1 to 9 , where 1 is the lowest income that is possible in society, and 9, on the contrary, is the highest possible income. The idea of adding exactly this variable is the following: we think that in reality trust is influenced not so much by the actual amount of the individual's income as by the individual's assessment of his income. Moreover, such measurement help as to account for possible difference of income between the regions, which is a common situation for Russia.

Our national fragmentation index is based on the racial fragmentation index of Alesina and La Ferrara (2002). It represents the probability that two randomly drawn individuals in a certain region belong to different nationalities, the index is thus increasing in heterogeneity. It is computed as follows:

$$
\text { Nationality } \text { Index }_{i}=1-\sum S_{k i}^{2}
$$

where $i$ represents a region and $k$ a nationality. Each term $S_{k i}$ represents the share of race $k$ in the total population of region $i$.
We add dummy variables of three most common religious groups in Russia: atheist, Orthodox and Muslim. We also add dummies of federal districts in which an individual lives.

\section{Analysis of trust determinants}

The first purpose of the following article is to identify the determinants of generalized trust in modern Russia. We would like to start with analyzing the most common factors found in existing papers. Table B.9 presents the results of random-effects ordered logistic model estimation. Due to the fact that in case of logistic models coefficients can not be interpreted in the usual way, the marginal effects of coefficients are presented. This table consists of two models, the difference of which will be explained later.

According to our results, in Russia men are more likely to trust people in general than women and this effect is significant for both models. This finding seems to be obvious since, as was mentioned above, women tend to trust less than men because of the gender discrimination which has been discussed much in recent years.

The marginal effect of variable Age is also significant, meaning older people are more likely to trust due to them having more experience in dealing with people, specifically due to their ability to recognize signals that can determine how trustworthy a person they are dealing with is. A similar logic applies to the discussion of individual's education. During the educational process individuals encounter unfamiliar to them groups of people and thus have increased opportunity to understand signals of trust-warranting information. Therefore, the higher the education of an individual, the more likely he or she to trust other people. The theoretical explanation is supported by our results: we have found that individuals with completed secondary specialized education and individuals with higher education are more likely to trust others than individuals with incomplete secondary education.

None of the marital status variables appear to influence trust level, except for the dummy variable that indicates if an individual is a widow or a widower. In the second model its effect is slightly significant (at a $10 \%$ significance level only) and negative, which shows that widows and widowers are less likely to trust than single people. This finding is consistent with literature which documents that people, who experienced some sort of trauma trust less. The effect of the number of respondent's children is insignificant for Russia.

The effect of living in a village or some sort of countryside is positive and strong, i.e. individuals living in a rural area are keen to trust more. We guess that such a result can be explained in a way that rural areas of Russia in most cases are small and relatively sparsely populated, so people living there should know each other better (as compared to a metropolis), trust each other and this in turn inclines them to trust people more 
in general. By the way, the same empirical result was received in the above-mentioned paper by Omelchenko, Maximova and Noyanzina (2018).

Income and success in the labor market are considered to be among the strongest factors affecting generalized trust. Having high income and being successful in the labor market is likely to promote trust because it provides people with the necessary resources to take risks and, therefore, trust others. The factor of success (in our case lack thereof) in the labor market is denoted by the dummy variable Unemployed, as employment status is usually specified as one of several criteria signifying labor market success. According to our finding, in Russia this factor does not affect generalized trust.

The two models in the table B.9 differ in the variable by which we denote individual's income. In the first model we use common in the articles on this topic variable of actual person's income (in our case that is the person's whole monthly income). Despite the fact that this determinant turned out to be highly significant in previous papers on this topic, in our article it did not. In the second model we use a unique in trust analyzing studies variable of individual's self-estimation of his or her income. According to the expectations, it is this factor that influences the generalized trust: the higher the self-esteem of the individual of his income, the more likely he or she trusts others. In the second model we also add the variable of the individual's assessment of his authority in the society, which appears to have positive and strong influence on a probability of the individual's transition to the category of "full trust".

It is worth noting that all the marginal effects remain almost the same in the models of the same specification, but with the addition of a time effect (such models can be provided upon request).

\subsection{Nationality \& religion and Trust}

Next, we move on to a group of exogenous variables that characterize national fragmentation in a region in which an individual lives, and a religious group to which a individual relates. The Table 1 presents the estimation results of random-effects ordered logistic models, including these exogenous variables. We would like to draw attention to the fact that these and the following regression models include a set of control variables, which are all the exogenous variables from the Model 1.2 from the Table B.9.

Random-effects ordered logistic models: nationality \& religion

Table 1

\begin{tabular}{l|l|l|l|l|l|l}
\hline \multirow{2}{*}{ Nationality index } & \multicolumn{3}{|c|}{ Model 2.1 } & \multicolumn{3}{c}{ Model 2.2 } \\
\cline { 2 - 7 } & trust $=0$ & trust $=1$ & trust $=2$ & trust $=0$ & trust $=1$ & trust $=2$ \\
\cline { 2 - 6 } Atheist & -0.031 & 0.017 & 0.014 & & & \\
& $(0.036)$ & $(0.019)$ & $(0.016)$ & & \\
Orthodox & & & 0.027 & -0.015 & -0.013 \\
& & & & $(0.041)$ & $(0.022)$ & $(0.019)$ \\
Muslim & & & 0.043 & -0.025 & -0.019 \\
& & & & $(0.037)$ & $(0.019)$ & $(0.017)$ \\
& & & & $-0.114^{* *}$ & $0.061^{* *}$ & $0.053^{* *}$ \\
Controls & & & & $(0,040)$ & $(0.022)$ & $(0.019)$ \\
$N$ & & & & & Yes & \\
\hline
\end{tabular}

Note: Marginal effects; standard errors in brackets; ${ }^{* *} p<0.001,{ }^{* *} p<0.01,{ }^{*} p<0.05, \cdot p<0.1$.

The Model 2.1 includes the variable, characterizing national fragmentation in a region in which an individual lives. Equation (1) introduces the formula for calculating the Nationality Index, which represents the probability that two randomly drawn individuals in a certain region belong to different nationalities. So, the index is increasing in heterogeneity. According, to the existing literature social distance between individuals acts as a barrier to developing trust, since people tend to trust those, who belong to the same to theirs group: income group, race group, nationality group, religious group, etc. That is why, in more homogeneous society individuals are more likely to trust others than in heterogeneous one.

As expected, in case of Russia, national fragmentation in a region does not affect trust level, since Russians are the largest group and includes $80 \%$ of the whole population.

\subsection{Political confidence and Trust}

Next, we move on to a group of exogenous variables of political confidence of an individual. The Table 2 presents the estimation results of random-effects ordered logistic models, including these exogenous variables. 
Random-effects ordered logistic models: political confidence

\begin{tabular}{|c|c|c|c|c|c|c|}
\hline & & Model 3.1 & & & Model 3.2 & \\
\hline & trust $=0$ & trust $=1$ & trust $=2$ & trust $=0$ & trust $=1$ & trust $=2$ \\
\hline$P C_{-} 1$ & $\begin{array}{l}0.003 \\
(0.005)\end{array}$ & $\begin{array}{l}-0.002 \\
(0.003)\end{array}$ & $\begin{array}{l}-0.001 \\
(0.003)\end{array}$ & & & \\
\hline$P C \_2$ & $\begin{array}{l}-0.036^{* * *} \\
(0.006)\end{array}$ & $\begin{array}{l}0.018^{* * *} \\
(0.003)\end{array}$ & $\begin{array}{l}0.017^{* * *} \\
(0.003)\end{array}$ & & & \\
\hline$P C_{-} 3$ & $\begin{array}{l}-0.029^{* * *} \\
(0.006)\end{array}$ & $\begin{array}{l}0.015^{* * *} \\
(0.003)\end{array}$ & $\begin{array}{l}0.014^{* * *} \\
(0.003)\end{array}$ & & & \\
\hline$P_{-} 4$ & $\begin{array}{l}-0.014^{*} \\
(0.005)\end{array}$ & $\begin{array}{l}0.007^{*} \\
(0.003)\end{array}$ & $\begin{array}{l}0.007^{*} \\
(0.003)\end{array}$ & & & \\
\hline$P C \_$index & & & & $\begin{array}{l}-0.013^{* * *} \\
(0.001)\end{array}$ & $\begin{array}{l}0.007^{* * *} \\
(0.001)\end{array}$ & $\begin{array}{l}0.006^{* * *} \\
(0.001)\end{array}$ \\
\hline $\begin{array}{l}\text { Controls } \\
N\end{array}$ & & $\begin{array}{c}\text { Yes } \\
11933\end{array}$ & & & $\begin{array}{c}\text { Yes } \\
11933\end{array}$ & \\
\hline
\end{tabular}

Note: Marginal effects; standard errors in brackets; ${ }^{* *} p<0.001,{ }^{* *} p<0.01,{ }^{*} p<0.05,{ }^{*} p<0.1$.

As can be seen in the table above, political confidence is a strong factor of generalized trust (be separate components and in common). The more confident an individual in political sphere and law of Russia, more likely he or she trusts other people.

\subsection{Job satisfaction and Trust}

Next, we move on to a group of exogenous variables of job satisfaction of an individual. The Table 3 presents the estimation results of random-effects ordered logistic models, including these exogenous variables.

Table 3

Random-effects ordered logistic models: job satisfaction

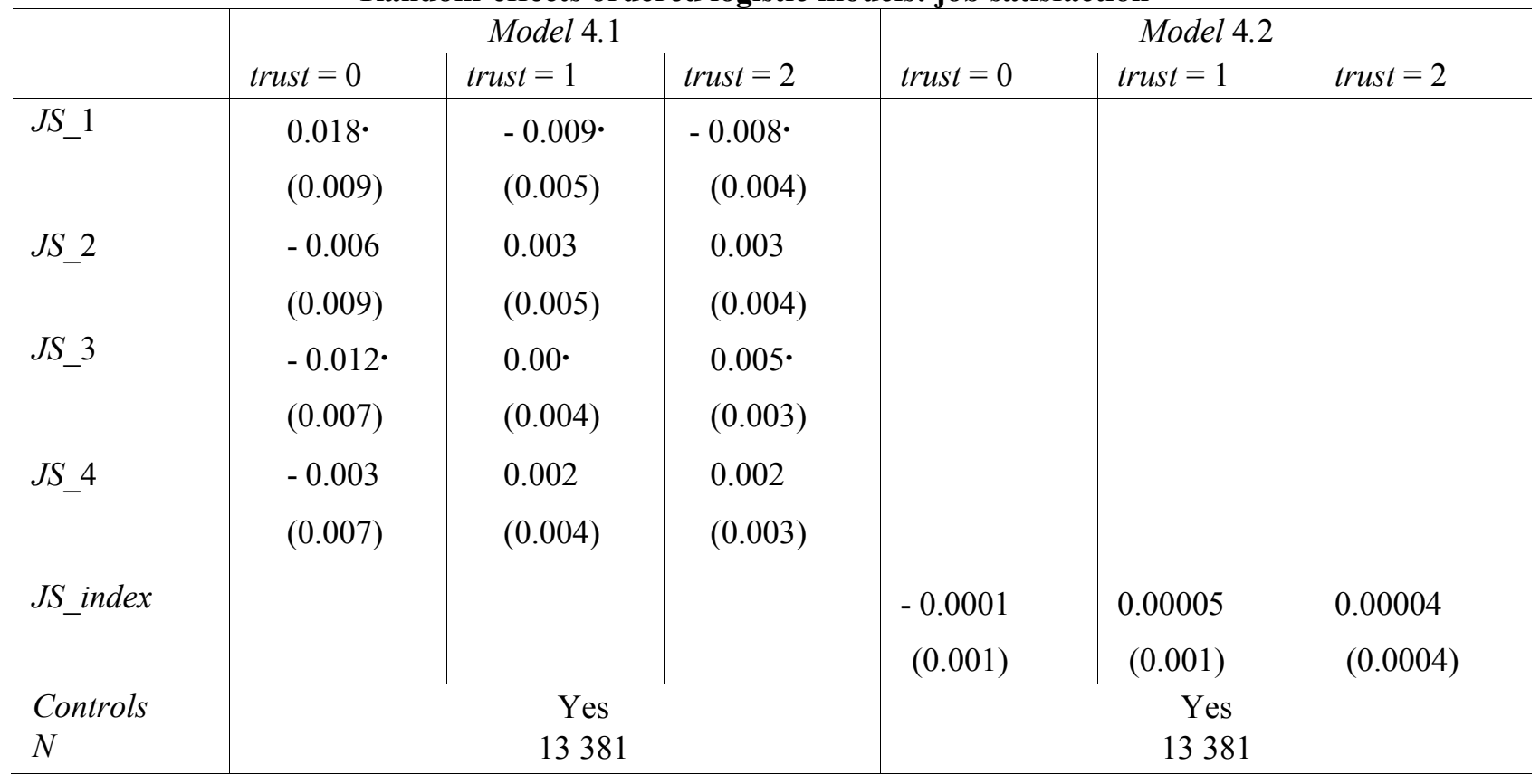

Note: Marginal effects; standard errors in brackets; ${ }^{* *} p<0.001,{ }^{* *} p<0.01,{ }^{*} p<0.05,{ }^{*} p<0.1$.

This factor does not affect trust by separate components and in common. 


\subsection{Egalitarian values and Trust}

The Table 4 presents the results of random-effects ordered logistic model estimation with exogenous variables assessing egalitarian values of an individual.
This factor does not affect generalized trust in common, but still some components of person's egalitarian value are significant.

Random-effects ordered logistic models: egalitarian values

\begin{tabular}{|c|c|c|c|c|c|c|}
\hline \multirow{3}{*}{$E V_{-} 1$} & \multicolumn{3}{|c|}{ Model 5.1} & \multicolumn{3}{|c|}{ Model 5.2} \\
\hline & trust $=0$ & trust $=1$ & trust $=2$ & trust $=0$ & trust $=1$ & trust $=2$ \\
\hline & $\begin{array}{l}-0.012 \\
(0.008)\end{array}$ & $\begin{array}{l}0.007 \\
(0.004)\end{array}$ & $\begin{array}{l}0.006 \\
(0.004)\end{array}$ & & & \\
\hline$E V \_2$ & $\begin{array}{l}0.006 \\
(0.012)\end{array}$ & $\begin{array}{l}-0.003 \\
(0.007)\end{array}$ & $\begin{array}{l}-0.003 \\
(0.006)\end{array}$ & & & \\
\hline$E V \_3$ & $\begin{array}{l}0.023^{* *} \\
(0.009)\end{array}$ & $\begin{array}{l}-0.012^{* *} \\
(0.005)\end{array}$ & $\begin{array}{l}-0.011^{* *} \\
(0.004)\end{array}$ & & & \\
\hline$E V \_4$ & $\begin{array}{l}0.003 \\
(0.008)\end{array}$ & $\begin{array}{l}-0.002 \\
(0.004)\end{array}$ & $\begin{array}{l}-0.001 \\
(0.004)\end{array}$ & & & \\
\hline$E V \_5$ & $\begin{array}{l}-0.031^{* * *} \\
(0.006)\end{array}$ & $\begin{array}{l}0.016^{* * *} \\
(0.003)\end{array}$ & $\begin{array}{l}0.015^{* * *} \\
(0.003)\end{array}$ & & & \\
\hline$E V \_6$ & $\begin{array}{l}0.023^{*} \\
(0.010)\end{array}$ & $\begin{array}{l}-0.012^{*} \\
(0.005)\end{array}$ & $\begin{array}{l}-0.011^{*} \\
(0.005)\end{array}$ & & & \\
\hline$E V \_7$ & $\begin{array}{c}-0.011 \cdot \\
(0.006)\end{array}$ & $\begin{array}{l}0.006^{\bullet} \\
(0.003)\end{array}$ & $\begin{array}{l}0.005^{\bullet} \\
(0.003)\end{array}$ & & & \\
\hline$E V \_$index & & & & $\begin{array}{l}-0.001 \\
(0.001)\end{array}$ & $\begin{array}{l}0.001 \\
(0.0005)\end{array}$ & $\begin{array}{l}0.001 \\
(0.0004)\end{array}$ \\
\hline $\begin{array}{l}\text { Controls } \\
N\end{array}$ & & $\begin{array}{c}\text { Yes } \\
12132\end{array}$ & & & $\begin{array}{c}\text { Yes } \\
12132\end{array}$ & \\
\hline
\end{tabular}

Note: Marginal effects; standard errors in brackets; ${ }^{* * *} p<0.001,{ }^{* *} p<0.01,{ }^{*} p<0.05,{ }^{*} p<0.1$.

\section{The crises and trust}

The second purpose of this study, as we mentioned earlier, is to check whether the economic crises of 20082009 and 2014-2015 affected the level of generalized trust with the assumption that the population over working age was not affected.

According to the existing literature, the level of particularized trust (i.e. trust to different institutions, such as, for example, government) after the crisis of 2008 has changed among European and American citizens and in the main it has decreased. However, there are no such studies about generalized trust and no studies on Russian data. Our expectation is that in Russia generalized trust level has also been changed after the crises (crises of 2008 and 2014) and, relying on previous works, it should have decreased.

To check this expectation we are going to use difference-in-difference model approach. The treatment group is respondents that were in working age $(<55)$ until 2016 (i.e. were in working age in all 3 years -2006 , $2012,2016)$ and control group is respondents that were over working age $(\geq 55)$ since 2006 (i.e. were over working age in all 3 years $-2006,2012,2016)$. The choice of such a treatment group is because we suggest that from an economic point of view crises affected harder people of working age (through layoffs, wage cuts, etc.) rather than people of retirement age. And we expect that this economic shock on the working-age population could cause a decline in the level of their generalized trust.

Just before the regression analysis it is useful to compare means of the whole sample and treatment group in these two years. As can be seen from the table, the mean values of trust of the whole sample and treatment group do not differ significantly in 2006, before the crises, and they do not differ significantly in 2016, after the crises. But the difference of the means are significant in 2012, after the first crisis of 2008.

On the first step, we take two years: 2006, as a precrises year, and 2016, as a post-crises year. So, firstly, we check the impact of both crises.

Table 5 presents the estimates of the two difference-in-difference ordered logistic models for the period 2006-2016 with the dependent variable of generalized trust: Model 7.1 without control variables and Model 7.2, on the contrary, with them. The variable of 
interest in case of difference-in-difference model is a cross product of treatment group dummy variable and dummy variable of post-experiment period. So, in our case it is cross product of variables Young and Year 2016 and it is significant both for models with and without control variables. What is interesting, we expected this variable to be significant, but we expected it to give negative impact on generalized trust. However, this variable positively influences trust, which means that respondents in a working age began to trust more after the crises. So, this result is rather surprising.

Difference-in-difference ordered logistic models: 2006-2016

\begin{tabular}{l|l|l|l|l|l|l}
\hline & \multicolumn{3}{|c|}{ Model 7.1 } & \multicolumn{3}{c}{ Model 7.2 } \\
\cline { 2 - 7 } & trust $=0$ & trust $=1$ & trust $=2$ & trust $=0$ & trust $=1$ & trust $=2$ \\
\hline Young & 0.003 & -0.001 & -0.001 & -0.0004 & -0.00005 & 0.0004 \\
& $(0.012)$ & $(0.005)$ & $(0.007)$ & $(0.024)$ & $(0.009)$ & $(0.015)$ \\
Year 2016 & $-0.096^{* * *}$ & $0.043^{* * *}$ & $0.053^{* * *}$ & $-0.112^{* * *}$ & $0.046^{* * *}$ & $0.066^{* * *}$ \\
& $(0.011)$ & $(0.005)$ & $(0.006)$ & $(0.014)$ & $(0.006)$ & $(0.009)$ \\
Young*2016 & $-0.098^{* * *}$ & $0.044^{* * *}$ & $0.054^{* * *}$ & $-0.114^{* * *}$ & $0.046^{* * *}$ & $0.067^{* * *}$ \\
& $(0.013)$ & $(0.006)$ & $(0.007)$ & $(0.017)$ & $(0.008)$ & $(0.010)$ \\
\hline Controls & \multicolumn{3}{c}{ No } & 7444 & & 4809 \\
\hline
\end{tabular}

Note: Marginal effects; standard errors in brackets; ${ }^{* * *} p<0.001,{ }^{* *} p<0.01,{ }^{*} p<0.05,{ }^{*} p<0.1$.

In the models below we do not distinguish crises, meanwhile, it is believed that the crises of 2008 and 2014 are quite different. The crisis of 2008 is considered to be a purely economic crisis, and the crisis of 2014 is more political than economic. Could the difference in the nature of these crises lead to unexpected results in the models above? To answer this question, we will build separate models for the periods of 2006-2012 and 2012-2016 to see the impact of the crises of 2008 and 2014 separately from each other.

Now we check the impact of the crisis of 2008 and we take two years: 2006, as a pre-crisis year, and 2012, as a post-crisis year.

Table 6 presents the estimates of the two difference-in-difference ordered logistic models for the period 2006-2012 with the dependent variable of generalized trust: Model 8.1 without control variables and
Model 8.2, on the contrary, with them. As can be seen from the table, effect of cross product of variables Young and Year 2012 is positive and significant in the first model without controls and negative and insigni ficant in the second model with controls. And in this situation it is better to orientate to the results of the second model, since the first model includes rather small number of variables and the effect of the variable of interest to us may be not pure, in contrast to the effect of the second variable, where this effect is much more pure due to the addition of control variables. That is why the impact of economic crisis of 2008 on working-age population is not significant (but it is still negative, as was expected).

Now we check the impact of the crisis of 2014 and we take two years: 2012, as a pre-crisis year, and 2016, as a post-crisis year.

Difference-in-difference ordered logistic models: 2006 - 2012

\begin{tabular}{|c|c|c|c|c|c|c|}
\hline & \multicolumn{3}{|c|}{ Model 8.1} & \multicolumn{3}{|c|}{ Model 8.2} \\
\hline & trust $=0$ & trust $=1$ & trust $=2$ & trust $=0$ & trust $=1$ & trust $=2$ \\
\hline Young & $\begin{array}{l}0.030^{*} \\
(0.012)\end{array}$ & $\begin{array}{l}-0.013^{*} \\
(0.006)\end{array}$ & $\begin{array}{l}-0.017^{*} \\
(0.006)\end{array}$ & $\begin{array}{l}0.006 \\
(0.022)\end{array}$ & $\begin{array}{l}-0.001 \\
(0.010)\end{array}$ & $\begin{array}{l}-0.005 \\
(0.012)\end{array}$ \\
\hline Year 2012 & $\begin{array}{l}-0.046^{* * *} \\
(0.011)\end{array}$ & $\begin{array}{l}0.022^{* * *} \\
(0.005)\end{array}$ & $\begin{array}{l}0.024^{* * *} \\
(0.006)\end{array}$ & $\begin{array}{l}-0.002 \\
(0.017)\end{array}$ & $\begin{array}{l}0.0001 \\
(0.008)\end{array}$ & $\begin{array}{l}0.002 \\
(0.009)\end{array}$ \\
\hline Young*2012 & $\begin{array}{l}-0.029^{*} \\
(0.013)\end{array}$ & $\begin{array}{l}0.014^{*} \\
(0.007)\end{array}$ & $\begin{array}{l}0.015^{*} \\
(0.007)\end{array}$ & $\begin{array}{l}0.025 \\
(0.021)\end{array}$ & $\begin{array}{l}-0.011 \\
(0.009)\end{array}$ & $\begin{array}{l}-0.014 \\
(0.011)\end{array}$ \\
\hline $\begin{array}{l}\text { Controls } \\
N\end{array}$ & \multicolumn{3}{|c|}{$\begin{array}{c}\text { No } \\
7444\end{array}$} & \multicolumn{3}{|c|}{$\begin{array}{c}\text { Yes } \\
4808\end{array}$} \\
\hline
\end{tabular}

Note: Marginal effects; standard errors in brackets; ${ }^{* * *} p<0.001,{ }^{* *} p<0.01,{ }^{*} p<0.05, \cdot p<0.1$. 
Table 7 presents the estimates of the two difference-in-difference ordered logistic models for the period 2012-2016 with the dependent variable of generalized trust: Model 9.1 without control variables and Model 9.2, on the contrary, with them. As can be seen from the table, effect of cross product of variables Young and Year 2016 is positive and significant in both models. So, we can suppose that economic-political crisis of 2014 has led to working-age population trusting others more.

Difference-in-difference ordered logistic models: 2012 - 2016

\begin{tabular}{l|l|l|l|l|l|l}
\hline \multirow{2}{*}{ Young } & \multicolumn{3}{|c|}{ Model 9.1 } & \multicolumn{3}{c}{ Model 9.2 } \\
\cline { 2 - 7 } & trust $=0$ & trust $=1$ & trust $=2$ & trust $=0$ & trust $=1$ & trust $=2$ \\
\hline \multirow{3}{*}{ Year 2016 } & $0.028^{*}$ & $-0.013^{*}$ & $-0.015^{*}$ & 0.039 & -0.017 & -0.022 \\
& $(0.012)$ & $(0.005)$ & $(0.007)$ & $(0.024)$ & $(0.009)$ & $(0.015)$ \\
& $-0.052^{* * *}$ & $0.024^{* * *}$ & $0.028^{* * *}$ & $-0.066^{* * *}$ & $0.026^{* * *}$ & $0.039^{* * *}$ \\
Young*2016 & $(0.011)$ & $(0.005)$ & $(0.006)$ & $(0.015)$ & $(0.006)$ & $(0.009)$ \\
& $-0.070^{* * *}$ & $0.032^{* * *}$ & $0.038^{* * *}$ & $-0.098^{* * *}$ & $0.039^{* * *}$ & $0.058^{* * *}$ \\
& $(0.013)$ & $(0.006)$ & $(0.007)$ & $(0.019)$ & $(0.008)$ & $(0.011)$ \\
\hline Controls & \multicolumn{3}{c}{ No } & 7444 & & 4 Yes \\
\hline
\end{tabular}

Note: Marginal effects; standard errors in brackets; ${ }^{* * *} p<0.001,{ }^{* *} p<0.01,{ }^{*} p<0.05, \cdot p<0.1$.

But can we say that this positive change was due to the crisis of 2014? We can not be completely sure about this. There were some big events in this period of time in Russia except for the crisis, which could in fact influence level of trust. First of all, that is an annexation of the Crimea in 2014, which, as Kolesnikov (2015) writes, caused a sense of national pride in Russian society. Secondly, that is Sochi Olympics in 2014, which caused the same effect. Maybe these events "overshadowed" negative consequences of the crisis and affected Russians in a positive way. Or maybe the political crisis, in particular the attacks from the West at this time, led the Russian people to unite. Another possible factor is political propaganda. Ponarin and Komin (2018) believe that propaganda of "imperial nationalism" allowed to rally the nation around its government and to feel happiness in spite of economic hardship. Perhaps, our empirical result confirms this effect of propaganda. In general, all the events described above are characterized by an increase in patriotism/propaganda, which could positively affect the level of generalized trust in the Russian society.

\section{Conclusion}

Although the concept of trust is not new to economic theory, nowadays there is the lack of empirical works, in particular those dedicated to assessment of the individual level determinants of trust. And, to our knowledge, there are no such works based on the surveys of the Russian citizens.

Our study shows that the strongest determinants of generalized trust in modern Russia are political confidence, which fosters trust, age, higher education, living in a countryside, which also have a significant influence on trust. Our finding, which is unique on the topic, is that at least in Russia self-esteem of an individual of his or her income is a significant factor, and actual level of income is not.

There is also a great lack of studies concerning the trust level change after the financial crises. There is some evidence, mostly from the surveys of the US citizens, that institutional trust has dramatically decreased after the crisis of 2008. But there is still an open question of what happened to the generalized individual trust after 2008. There were not such studies in Russia as well.

We find that crises of different nature have different impact on generalized trust. The crisis of 2008, which is said to be purely economic, did not affect trust level, while the crisis of 2014, which is said to be economicpolitical, affected trust in a positive direction. There were some big events, which caused a sense of national pride in Russian society in this period of time as well. So, the effect of patriotism or propaganda "overshadowed" negative consequences of the economic recession.

A policy conclusion that emerges from this study is that identifying the barriers to social integration government may help increase the level of trust, which will possibly lead to stronger institutions and economic growth. The future perspectives of this research can be, in particular, concerned with use of data from World Values Surveys (WVS). 


\section{Appendices}

Appendix A. Variable descriptions and summary statistics

Table A.8

Variable descriptions and summary statistics

\begin{tabular}{|c|c|c|c|c|}
\hline Variable name & Description & Mean & $S D$ & $N$ \\
\hline 1 & 2 & 3 & 4 & 5 \\
\hline Trust & $\begin{array}{l}=2 \text {, if an individual states that "Most people can be } \\
\text { trusted" } \\
=1 \text {, if an individual trusts or does not trust depending } \\
\text { on the person and situation } \\
=0 \text {, if an individual states that "In dealing with other } \\
\text { people, one must always be careful" }\end{array}$ & 0.634 & 0.739 & 14358 \\
\hline Male & $=1$, if an individual is male & 0.378 & 0.485 & 14358 \\
\hline Age & Number of full years & 49.186 & 16.035 & 14358 \\
\hline Income & $\begin{array}{l}\text { Full deflated monthly income of an individual (in- } \\
\text { cludes all cash inflows, such as salaries, pensions, bo- } \\
\text { nuses, profits, allowances, material assistance, casual } \\
\text { earnings and other inflows) }\end{array}$ & 8275.286 & 10997.410 & 14086 \\
\hline Rural & $=1$, if an individual lives in a village or a township & 0.396 & 0.489 & 14358 \\
\hline Children & Number of children & 1.512 & 0.947 & 14358 \\
\hline Place size & Population in a settlement in which an individual lives & 1100353 & 2883531 & 14358 \\
\hline Income scale & $\begin{array}{l}\text { "Imagine a ladder of } 9 \text { steps, where on the lowest one } \\
\left(\text { the } 1^{s t} \text { ) there are beggars, and on the highest one (the }\right. \\
9^{t h} \text { ) are rich. On which of the nine steps are you today } \\
\text { personally?" }\end{array}$ & 3.949 & 1.436 & 14126 \\
\hline Authority scale & $\begin{array}{l}\text { "Imagine a ladder of } 9 \text { steps, where on the lowest one } \\
\text { (the } 1^{s t} \text { ) there are completely powerless, and on the } \\
\text { highest one (the } 9^{\text {th }} \text { ) are those who have the greatest } \\
\text { authority. On which of the nine steps are you today } \\
\text { personally?" }\end{array}$ & 3.762 & 1.617 & 14078 \\
\hline SP since 16 & $\begin{array}{l}=1 \text {, if an individual lives in the same settlement since } \\
\text { the age of } 16\end{array}$ & 0.426 & 0.495 & 14281 \\
\hline Unemployed & $=1$, if an individual is unemployed & 0.107 & 0.309 & 14286 \\
\hline \multicolumn{5}{|l|}{ Marital status } \\
\hline Single & $=1$, if an individual is single & 0.092 & 0.289 & 14347 \\
\hline Married & $=1, \mathrm{i}$ & 0.683 & 0.465 & 14347 \\
\hline Divorced & $=1$, if an individual is divorced & 0.091 & 0.288 & 14347 \\
\hline Widow & $=1$, if an individual is widow or widower & 0.134 & 0.340 & 14347 \\
\hline \multicolumn{5}{|l|}{ Education } \\
\hline Education_1 & $\begin{array}{l}=1 \text {, if an individual has incomplete secondary educa- } \\
\text { tion }\end{array}$ & 0.191 & 0.393 & 14325 \\
\hline Education_2 & $=1$, if an individual has complete secondary education & 0.314 & 0.464 & 14325 \\
\hline Education_3 & $\begin{array}{l}=1 \text {, if an individual has complete specialized se- } \\
\text { condary education }\end{array}$ & 0.252 & 0.434 & 14325 \\
\hline Education_4 & $=1$, if an individual has higher education & 0.242 & 0.428 & 14325 \\
\hline \multicolumn{5}{|l|}{ Federal districts } \\
\hline Central & $=1$, if an individual lives in the Central Federal District & 0.259 & 0.438 & 14358 \\
\hline Northwest & $\begin{array}{l}=1 \text {, if an individual lives in the Northwest Federal Dis- } \\
\text { trict }\end{array}$ & 0.078 & 0.267 & 14358 \\
\hline South & $=1$, if an individual lives in the South Federal District & 0.105 & 0.306 & 14358 \\
\hline North Caucasus & $=1$, if an individual lives in the Volga Federal District & 0.095 & 0.293 & 14358 \\
\hline
\end{tabular}


A. Kustova, I. Rozmainsky

\begin{tabular}{|c|c|c|c|c|}
\hline \multicolumn{5}{|c|}{ Ending of Table A.8 } \\
\hline 1 & 2 & 3 & 4 & 5 \\
\hline Volga & $\begin{array}{l}=1 \text {, if an individual lives in the North Caucasus Fed- } \\
\text { eral District }\end{array}$ & 0.234 & 0.423 & 14358 \\
\hline Ural & $=1$, if an individual lives in the Ural Federal District & 0.056 & 0.230 & 14358 \\
\hline Siberia & $=1$, if an individual lives in the Siberia Federal District & 0.135 & 0.342 & 14358 \\
\hline Far East & $\begin{array}{l}=1 \text {, if an individual lives in the Far East Federal Dis- } \\
\text { trict }\end{array}$ & 0.038 & 0.190 & 14358 \\
\hline \multicolumn{5}{|l|}{$\underline{\text { Religions }}$} \\
\hline Atheist & $=1$, if an individual is atheist & 0.069 & 0.254 & 14358 \\
\hline Orthodox & $=1$, if an individual professes Orthodoxy & 0.821 & 0.384 & 14358 \\
\hline Muslim & $=1$, if an individual professes Islam & 0.093 & 0.289 & 14358 \\
\hline \multicolumn{5}{|c|}{ Political and law confi- Set of $\mathrm{r}$} \\
\hline dence & $1=$ completely agree $; 5=$ completely disagree: & & & \\
\hline$P C_{-} 1$ & $\begin{array}{l}\text { "If a person considers the law to be unfair, he has the } \\
\text { right to circumvent him" }\end{array}$ & 3.594 & 1.146 & 13786 \\
\hline$P C_{-} 2$ & |"Judges in Russia are corrupt" & 2.643 & 1.100 & 12929 \\
\hline $\mathrm{PC}_{-}^{-3}$ & "In Russia you can not live without breaking the laws" & 2.878 & 1.157 & 13698 \\
\hline$P_{-}^{-} 4$ & $\begin{array}{l}\text { "If the highest state or political figures do not comply } \\
\text { with the laws, then ordinary people may not comply } \\
\text { with laws" }\end{array}$ & 3.265 & 1.227 & 13549 \\
\hline Egalitarian values & Set of rank variables & & & \\
\hline & $1=$ not important at all; $5=$ very important: & & & \\
\hline $\begin{array}{l}E V-1 \\
E V 2\end{array}$ & "Presence of equal and fair elections in Russia" & 4.334 & $\begin{array}{l}0.841 \\
0585\end{array}$ & $\begin{array}{l}14166 \\
14241\end{array}$ \\
\hline$E V 3$ & "Presence of law and order in Russia" & $\begin{array}{l}4.045 \\
4.131\end{array}$ & 0.898 & 14131 \\
\hline$E V^{-} 4$ & "Presence of independent media in Russia" & 3.915 & 1.008 & 13957 \\
\hline$E V 5$ & "Presence of political opposition in Russia" & 3.615 & 1.150 & 13025 \\
\hline$E V^{-} 6$ & "Presence of fair courts in Russia" & 4.594 & 0.650 & 14134 \\
\hline$E \bar{V}-7$ & $\begin{array}{l}\text { "Presence of protection of the rights of national, reli- } \\
\text { gious and other minorities in Russia" }\end{array}$ & 3.864 & 1.071 & 13376 \\
\hline Job satisfaction & Set of rank variables & & & \\
\hline$J S \_1$ & $\begin{array}{l}1=\text { not satisfied at all; } 5=\text { fully satisfied: } \\
\text { "How satisfied or dissatisfied are you with your work } \\
\text { as a whole?" }\end{array}$ & 2.045 & 1.908 & 14274 \\
\hline$J S \_2$ & $\begin{array}{l}\text { "How satisfied or dissatisfied are you with the condi- } \\
\text { tions of your work?" }\end{array}$ & 2.004 & 1.889 & 14263 \\
\hline$J S \_3$ & $\begin{array}{l}\text { "How satisfied or dissatisfied are you with the pay- } \\
\text { ment of your work?" }\end{array}$ & 1.585 & 1.635 & 14240 \\
\hline$J S \_4$ & $\begin{array}{l}\text { "How satisfied or dissatisfied are you with the oppor- } \\
\text { tunities for your professional growth?" }\end{array}$ & 1.749 & 1.769 & 13876 \\
\hline
\end{tabular}

Source: 2016, 2012, 2006 RLMS-HSE.

Note: statistics are based on a full sample. 
Table B.9

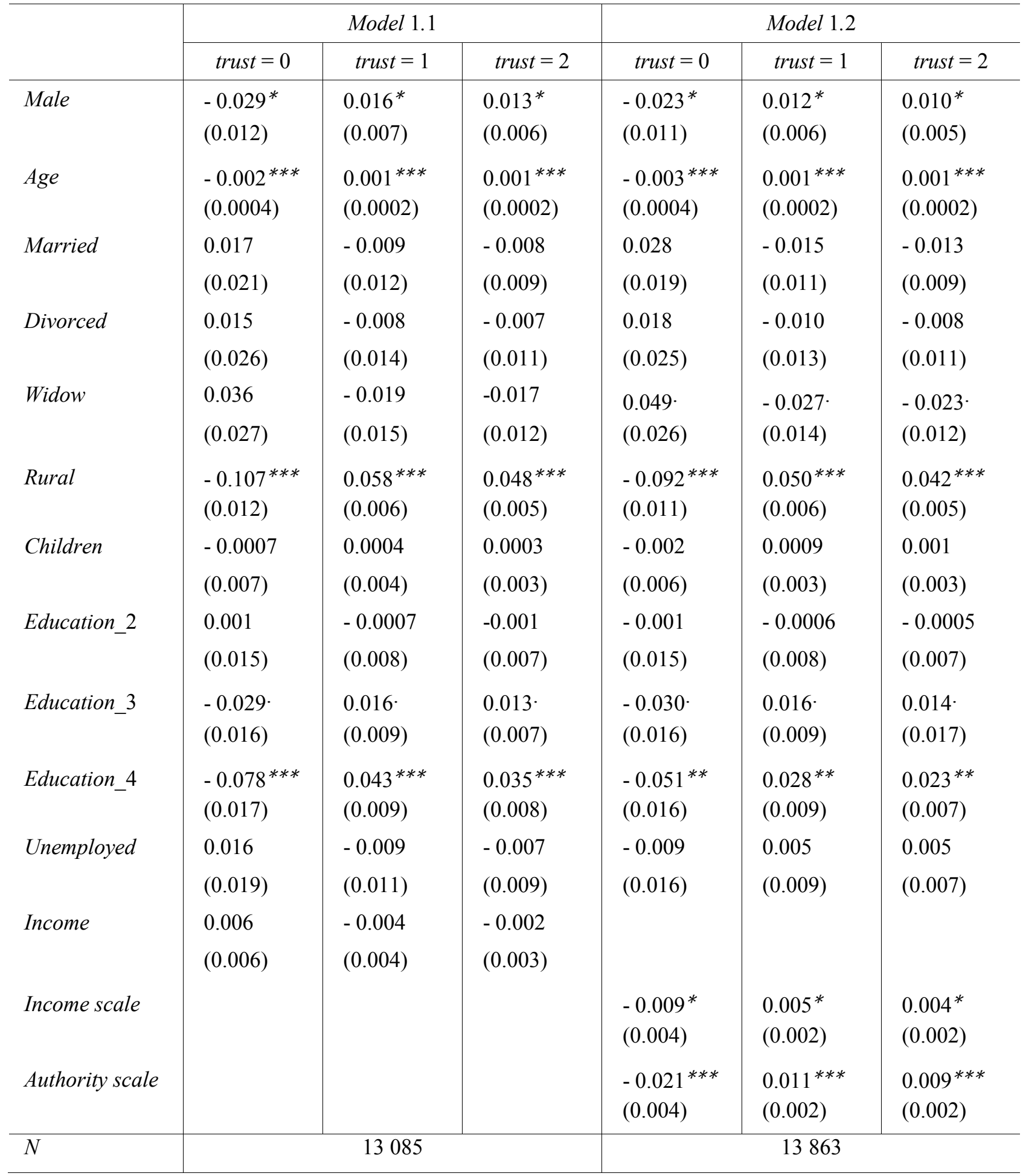

Note: Marginal effects; standard errors in brackets; ${ }^{* *} p<0.001,{ }^{* *} p<0.01,{ }^{*} p<0.05, \cdot p<0.1$

\section{References}

1. Alesina, A. and E. La Ferrara. (2002). Who trusts others? Journal of public economics, 85 (2), pp. 207-234.

2. Algan, Y. and Cahuc, P. (2010). Inherited trust and growth. American Economic Review, 100 (5), pp. 2060 2092.
3. Arrow, K. J. (1972). Gifts and exchanges. Philosophy \& Public Affairs, pp. 343-362.

4. Bjørnskov, C. (2007). Determinants of generalized trust: A cross-country comparison. Public Choice, 130 (1/2), pp. 1-21. 
5. Bjørnskov, C. (2012). How does social trust affect economic growth? Southern Economic Journal, 78 (4), pp. 1346-1368.

6. Brehm, J. and Rahn W. (1997). Individual-level evidence for the causes and consequences of social capital. American Journal of Political Science, pp. 999-1023.

7. Chan, K. S. (2007). Trade, social values, and the generalized trust. Southern Economic Journal, 73 (3), pp. $733-753$.

8. Delhey, J. and Newton, K. (2005). Predicting cross-national levels of social trust: global pattern or nordic exceptionalism? European Sociological Review, 21 (4), pp. 311-327.

9. Dohmen, T., Falk, A., Huffman, D. and Sunde, U. (2008). Representative trust and reciprocity: Prevalence and determinants. Economic Inquiry, 46 (1), pp. 84-90.

10. Freitag, M. and Traunmüller, R. (2009). Spheres of trust: An empirical analysis of the foundations of particularised and generalised trust. European Journal of Political Research, 48 (6), pp. 782-803.

11. Gambetta, D. and Hamill, H. (2005). Streetwise: How Taxi Drivers Establish Customer's Trustworthiness. Russell Sage Foundation.

12. Gleave, E., Robbins, B. and Kolko, B. (2012). Trust in uzbekistan. International Political Science Review, 33 (2), pp. 209-229.

13. Gros, D. and Roth, F. (2009). The crisis and citizens' trust in central banks. VoxEU. com 10, 4.

14. Hooghe, M., Reeskens, T., Stolle, D. and Trappers, A. (2009). Ethnic diversity and generalized trust in Europe: A cross-national multilevel study. Comparative Political Studies, 42 (2), pp. 198-223.

15. Jamal, A. (2007). When is social trust a desirable outcome? Examining levels of trust in the arab world. Comparative Political Studies, 40 (11), pp. 1328-1349.

16. Kolesnikov, A. I. (2015). Russian ideology after Crimea. Number s 1. Carnegie Moscow Center [In Russian].

17. Luhmann, N. (2018). Trust and Power. John Wiley \& Sons.

18. Marschall, M. J. and Stolle, D. (2004). Race and the city: neighborhood context and the development of generalized trust. Political Behavior, 26 (2), pp. 125 - 153.

19. Mill, J. S. (1970). Principles of Political Economy. Penguin Books.

20. Omelchenko, D. A., Maximova, S. G., and Noyanzina, O. E. (2018). Generalized trust in Russian border regions as indicator of social safety. Society and Security Insights, 2, pp. 11-28 [In Russian].

21. Paxton, P. (2007). Association memberships and generalized trust: A multilevel model across 31 countries. Social Forces, 86 (1), pp. 47-76.

22. Ponarin, E. and Komin, M. (2018). The Russian elite's imperial nationalism and the Russian society: The emergence of a grand consensus. Sociology Compass, 12 (12), pp. 1-16.

23. Putnam, R. D. (2000). Bowling alone: America's declining social capital. In Culture and politics, pp. 223234. Springer.

24. Rothstein, B. and Stolle, D. (2008). The state and social capital: Institutional theory of generalized trust. Comparative Politics, 40 (4), pp. 441-459.
25. Sapienza, P. and Zingales, L. (2012). A trust crisis. International Review of Finance, 12 (2), pp. 123-131.

26. Stolle, D. (1998). Bowling together, bowling alone: the development of generalized trust in voluntary associations. Political Psychology, 19 (3), pp. 497-525.

27. Tan, S. J. and Tambyah, S. K. (2011). Generalized trust and trust in institutions in Confucian Asia. Social Indicators Research, 103 (3), pp. 357-377.

28. Uslaner, E. M. (2002). The Moral Foundations of Trust. Cambridge University Press.

29. Uslaner, E. M. (2010). Trust and the economic crisis of 2008. Corporate Reputation Review, 13 (2), pp. $110-123$.

30. Welch, M. R., Sikkink, D., and Loveland, M. T. (2007). The radius of trust: Religion, social embeddedness and trust in strangers. Social Forces, 86 (1), pp. 23-46.

31. Zak, P. J. and Knack, S. (2001). Trust and growth. The Economic Journal, 111 (470), pp. 295-321.

Кустова А., Розмаїнський І. Емпіричний аналіз узагальненої довіри в сучасній Росії

Поняття довіри відіграє важливу роль в економічній теорії, але відсутні роботи, присвячені як детермінантам узагальненої довіри в сучасній Росії, так і співвідношенням між кризами і довірою. Російська економіка пережила кілька серйозних рецесій в останні роки, найважчими з яких були кризи 2008 і 2014 рр. Було б цікаво перевірити, чи змінився рівень довіри після цих подій у Росії. Це дослідження переслідує дві мети: перша - виявити детермінанти довіри в сучасній Росії, друга - перевірити, наскільки економічні кризи 20082009 pp. і 2014-2015 pр. вплинули на рівень загальної довіри при допущенні, що береться до уваги тільки населення працездатного віку. Дослідження засноване на даних RLMS-HSE. Для цілей цієї статті використовуються впорядковані логістичні моделі з випадковими ефектами і впорядковані логістичні моделі різниці різниць. Автори роблять висновки про те, що найважливішими детермінантами довіри є політична впевненість, вік, проживання в сільській місцевості, вища освіта. Криза 2008 р. не вплинула на довіру, тоді як криза 2014 р. надала на неї позитивного впливу через «ефект пропаганди».

Ключові слова: узагальнена довіра; фінансова криза; впорядкована логістична регресійна модель, регресійна модель різниці різниць.

Kustova A., Rozmainsky I. Empirical Analysis of Generalized Trust in Modern Russia

Today the concept of trust plays an important role in economics, but there is a lack of both works devoted to the determinants of generalized trust in modern Russia and relationships between the crises and trust. The Russian economy has suffered several significant recessions in recent years, the most serious of which were crises of 2008 and 2014. It would be interesting to check whether there was a trust change after these events in Russia. The current study has two purposes: the first one is to identify determinants of trust in modern Russia, the second one is to check whether the economic crises of 2008-2009 and 2014-2015 affected the level of generalized trust with the assumption that only population of working age was affected. The 
study is based on the RLMS-HSE survey. For the purposes of this paper the random-effects ordered logistic models and difference-in-difference ordered logistic models are used. We conclude that the most important determinants of trust are political confidence, age, living in a countryside, higher education; the 2008 crisis did not make influence on trust, where as the 2014 crisis affected on the trust in a positive direction due to the "propaganda effect".

Keywords: generalized trust, financial crisis, ordered logistic regression model, difference-in-difference regression model.

Кустова А., Розмаинский И. Эмпирический анализ обобщённого доверия в современной России

Сегодня понятие доверия играет важную роль в экономической теории, но отсутствуют работы, посвященные как детерминантам обобщённого доверия в современной России, так и соотношениям между кризисами и доверием. Российская экономика пережила несколько серьезных рецессий в последние годы, самыми тяжёлыми из которых были кризисы 2008 и 2014 гг.
Было бы интересно проверить, изменился ли уровень доверия после этих событий в России. Настоящее исследование преследует две цели: первая - выявить детерминанты доверия в современной России, вторая проверить, насколько экономические кризисы 20082009 гг. и 2014-2015 гг. повлияли на уровень общего доверия при допущении, что принимается во внимание только население трудоспособного возраста. Исследование основано на данных RLMS-HSE. Для целей данной статьи используются упорядоченные логистические модели со случайными эффектами и упорядоченные логистические модели разности разностей. Авторы делают выводы о том, что важнейшими детерминантами доверия являются политическая уверенность, возраст, проживание в сельской местности, высшее образование; Кризис 2008 г. не повлиял на доверие, тогда как кризис 2014 г. оказал на него положительное воздействия из-за «эффекта пропаганды».

Ключевые слова: обобщенное доверие; финансовый кризис; упорядоченная логистическая регрессионная модель, регрессионная модель разности разностей.

Received by the editors: 30.11 .2020 and final form 29.12.2020 